УДК 378.091.4 : 373+159 (477)

DOI: 10.37026/2520-6427-2019-99-3-86-88
Анатолій ЛУЦЮК,

кандидат педагогічних наук, доцент, завідувач кафедри педагогіки і психологіі Волинського ІППО

Олександр ОСТАПЙОВСьКИЙ, кандидат психологічних наук, дочент кафедри педагогіки і психологї Волинського ІППО

\title{
ПСИХОЛОГО-ПЕДАГОГІЧНІ АСПЕКТИ У СПАДЩИНІ В. О. СУХОМЛИНСЬКОГО В КОНТЕКСТІ НОВОЇ УКРАЇНСЬКОЇ ШКОЛИ
}

У статті розглянуто окремі наукові педагогічні та психологічні погляди в теорії та практищі спадшини відомого у всьому світі украӥнського педагога-новатора В. О. Сухомлинського, а також представлено їх використання у проиесі реалізації кониепиії «Нова українська школа».

Ключові слова: педагогіка, психологія, Нова украӥнська школа, особистість учителя, дитина, дослідницька робота.

В статье рассмотрены отдельные научные педагогические и психологические взгляды в теории и практике наследия всемирно известного украинского педагога-новатора В. А. Сухомлинского, а также представлено их использование в прочессе реализаичии кониепиии «Новая украинская школа».

Ключевые слова: педагогика, психология, Новая украинская школа, личность учителя, ребенок, исследовательская работа.

The pedagogical and psychological views of the Ukrainian educator $V$. O. Sukhomlynskyi, well-known throughout the world, and their use in the process of of the New Ukrainian School concept realization are considered in the article. In today's context, the professional activity of a teacher has undergone a significant transformation and is dependent on socio-cultural changes in Ukraine. The psychological and pedagogical system in Pavlysh secondary school, in the center of which the child is a unique personality, enriched science with innovative ideas, significantly expanded educational practice, is a kind of a modernization stage in the national education development and deserves its use in the pedagogical education. The role of postgraduate education as an independent link in the educational psychological and pedagogical process, has especially increased in the context of the New Ukrainian School ideas.

According to V. O. Sukhomlynskyi, pedagogical and psychological culture represents a certain degree of the teacher's socio-cultural experience of humanity mastery, deep knowledge of the methodology and the ability to use it in practice through innovative forms in the educational process. He was convinced that high psychological and pedagogical competence was an integral part of the teacher's professional culture. The innovative approach of V. O. Sukhomlynskyi to solve this problem with the pedagogical staff of Pavlysh secondary school is reflected in the organization of the psychological seminar, as well as the psychological commission.

The New Ukrainian School concept advances requirements not only to the educational system, but also to the teacher himself. The concentrated expression of these requirements is innovation, a constant desire to work in the chosen profession, to show creativity, to research, to use new methods in the practice of educational institutions work. V. O. Sukhomlynskyi, by his own scientific and practical activity as a principle of a rural school which became the world laboratory of innovative use of pedagogy and psychology, left relevant tips on managing the educational process on a psychological and pedagogical basis in the New Ukrainian School context.

Key words: New Ukrainian School, culture, pedagogy, psychological seminar, psychological commission, child, teacher, innovation, school principle.

Постановка проблеми. Входження України до європейського товариства можливе через формування демократичного суспільства, що потребує змін у вихованні і навчанні людини. Все це змінює статус освіти, відбувається переосмислення ролі педагогіки і психології як наук, які причетні до реформи школи. Саме ці проблеми були в центрі уваги значної кількості вчених і педагогів-новаторів упродовж історії становлення новітньої освіти. Постать українського педагога-гуманіста В. О. Сухомлинського є такою ж неперевершеною в цих питаннях, як постать Г. Ващенка, Л. Виготського, Д. Ельконіна, О. Киричука, Г. Костюка, С. Русової, А. Макаренка, К. Ушинського та ін. Він був генератором багатьох ідей, які вказують інноваційні шляхи розвитку як для педагогіки, так i для психології, особливо в процесі реалізації концепції «Нова українська школа».

Роль післядипломної освіти як самостійної ланки освітнього психолого-педагогічного процесу особливо зросла в контексті ідей Нової української школи. Зумовлено це тим, що державі в період реформування освітньої галузі потрібні висококваліфіковані компетентні працівники. Сучасна система післядипломної освіти має грунтуватися на концепції неперервної освіти, яка прийнята за стратегічну в цивілізованих країнах світу. Принцип «освіта впродовж усього життя» набуває 3 кожним роком усе більшого практичного звучання. Основну роль у післядипломній освіті слід відводити перебудові стереотипів діяльності 
й мислення педагогів через використання інноваційних наукових педагогічних і психологічних положень для реалізації завдань Нової української школи. При цьому для досягнення позитивних результатів необхідно використовувати досвід педагогів-новаторів, яким і є В. О. Сухомлинський.

Аналіз наукових досліджень і публікацій із проблеми використання педагогіки і психології у творчій спадщині В. О. Сухомлинського відображений у наукових дослідженнях вітчизняних учених (М. Антонця, І. Беха, В. Бондаря, М. Вашуленка, С. Гончаренка, I. Зязюна, В. Кременя, Н. Ничкало, О. Савченко, О. Сухомлинської, М. Ярмаченка та інших). У період інноваційних змін у системі освіти для наукової і практичної реалізації завдань Нової української школи результати проведених досліджень є методологічною базою для виховання особистості, патріота, інноватора.

Мета статті - на основі проведеного нами дослідження психолого-педагогічної системи В. О. Сухомлинського розглянути технологію іiі використання в освітньому середовищі оновленої української школи.

Виклад основного матеріалу. Аналіз В. О. Сухомлинським власного новаторського досвіду з питань використання педагогіки і психології щодо розвитку компетентностей учителів відображений ним у значній кількості праць, насамперед у широковідомих книгах «Павлиська середня школа», «Серце віддаю дітям», «Розмова $з$ молодим директором», «Як виховати справжню людину», «Сто порад учителеві», а також у дисертаційному дослідженні «Директор школи - керівник навчально-виховної роботи», що є скарбницею психолого-педагогічної майстерності вчителя.

В умовах розбудови в Україні національної системи освіти школа «як колиска народу», «колиска духу і культури народної» стає «святинею і надією народу», а іiі вчитель - «головним скульптором» дитячої душі, першим світочем у житті школяра, який пробуджує потяг до знань, повагу до нації, культури, освіти. Тому й нині зразком високоефективного вирішення згаданих завдань $є$ науково-практична діяльність видатного педагога В. О. Сухомлинського. Його основні методологічні позиції такі: школа - це насамперед учитель, особистість учителя - наріжний камінь виховання, якому народ ввіряє своє майбутнє. У період становлення Нової української школи місія вчителя в тому, щоб кожен учень усвідомлював себе «громадянином, хранителем духу народу, його ідей, його багатств $\mathrm{i}$ цінностей, його неминущої величі» [8, с. 338].

Педагогічна і психологічна культура представляє собою певний ступінь оволодіння вчителем соціокультурним досвідом людства, глибоке знання методології наук та вміння використовувати досягнення педагогіки і психології на практиці в різноманітних інноваційних формах у процесі становлення Нової української школи. «Це жива, творча педагогіка повсякденної праці, - писав В.О.Сухомлинський, - та педагогіка, в якій теоретичні закономірності процесу впливу на духовний світ виховання ніби зливаються з особистістю вчителя...; це, образно кажучи, техніка і технологія взаємодії майстра й об'єкта його праці...; це багатогранність, різноманітність, відточеність, зразковий стан інструментів нашої творчості, вміння володіти ними, як прекрасний музикант володіє скрипкою» [4].

Знати дитину 3 дитинства - один із найважливіших елементів педагогічної майстерності вчителя. В. О. Сухомлинський був певний у тому, що висока психолого-педагогічна компетентність є складовою професійної культури вчителя.
У зв’язку з цим він постійно наголошував, що не можна виховати дитину, не знаючи іiі вікових та індивідуальних особливостей, а залежно від цього змінюються і методи виховання. «Якщо педагогіку можна порівнювати 3 майстернею, де творяться складні прилади, писав Василь Олександрович, - то психологія в цій майстерні - найскладніші інструменти. Не буде інструментів, або вони стануть неточними - від майстерні залишаться одні стіни» [5, с. 612].

Новаторський підхід В. О. Сухомлинського 3 вирішення цієї проблеми в педагогічному колективі полягає в тому, що у Павлиській середній школі в 50 - 60-х рр., а в практиці сучасних шкіл - лише в 90-х рр., був організований психологічний семінар, а також психологічна комісія, яка готувала заняття для вчителів і надавала їм рекомендації $з$ дитячої психології. Можемо беззаперечно стверджувати, що саме завдяки геніальній науково-практичній роботі В. О. Сухомлинського були внесені інноваційні зміни в організацію управління освітнім процесом школи на психологічній основі. «Якщо ви хочете, щоб керівництво школою, - писав він, - було побудоване на науковій основі, щоб практична робота збагачувала теоретичні знання кожного вчителя, щоб у міру набуття практичного досвіду підвищувався рівень його педагогічної культури, починайте із психології та дефектології. Створіть психологічну комісію, самі займіться вивченням дитини, досліджуйте, спостерігайте, пробуджуйте колективну думку» [7, с. 459].

На окрему увагу заслуговують психологічні семінари, які проводилися в Павлиші раз на півтора місяця. Кожен учитель готував грунтовну доповідь про свої спостереження за одним з учнів, обов'язковою складовою якої були дані про результати періодичного медичного обстеження та спостереження лікаря. Дуже корисним на цих семінарах було дискусійне обговорення питань про причини певних педагогічних проблем, які виникали в розвитку дитини як особистості. Колектив шукав відповіді на питання, які ставило життя. Народжувалися нові ідеї. «Адже педагогічна ідея це крила, на яких злітає колективна творчість, - писав Василь Олександрович. - Ідея надихає колектив, і починається найцікавіше та найпотрібніше в шкільному житті - колективна дослідницька робота» [7, с. 74-75].

Для того, щоб досягнути результативності в роботі з дітьми Нової української школи, вчителеві необхідно передусім змінити свою позицію так, щоб його робота будувалася на принципах психолого-педагогічної взаємодії. В. О. Сухомлинський засуджував і застерігав учителів від агресії проти дитини. Вчитель не має права демонстративно наголошувати на слабких сторонах дитини. Його завдання полягає в тому, щоб створити такі умови діяльності учня, де він проявив би свої позитивні якості. Педагог повинен будувати свої стосунки 3 учнями на грунті поваги та справедливості, віри в здібності окремого учня. «Тільки той, хто вірить у Людину, може стати справжнім майстром» [7, с. 478].

Модернізація сучасної школи, концепція «Нова українська школа» висуває певні вимоги не лише до освітньої системи, але й до самого вчителя. Концентрованим виразом цих вимог $є$ інноваційність - постійне бажання працювати за обраною професією, проявляти творчість, досліджувати, упроваджувати нововведення в практику роботи закладів освіти, що має прийти на зміну інертності, пасивності і консерватизму, який нерідко панує серед певної частини педагогічних кадрів.

Теоретично і практично проблема дослідницької роботи у школі реалізована у творчій спадщині педагога-новатора В. О. Сухомлинського. 
Він вважав, що «за самою своєю логікою, за філософською основою, за творчим характером педагогічна праця неможлива без елемента дослідження і насамперед тому, що кожна людська індивідуальність, 3 якою ми маємо справу, це певною мірою своєрідний, неповторний світ думок, почуттів, інтересів». «У самій своїй основі педагогічна праця - справжня творча праця - стоїть близько до наукового дослідження» [7, с. 471-472]. Тому впродовж своєї управлінської діяльності директор Павлиської середньої школи плекав із кожного вчителя дослідника-практика 3 педагогіки і психології.

В. О. Сухомлинський власною науковою і практичною діяльністю на посаді директора сільської школи, яка стала світовою лабораторією інноваційного використання педагогіки і психології, залишив актуальну пораду своїм колегам - директорам закладів загальної середньої освіти Нової української школи: «Уміння керувати колективом залежить від того, наскільки глибоко розуміє керівник найтонші деталі педагогічного процесу, його глибинні джерела духовний світ школяра, особливості його розумової праці, процес опанування знань, формування переконань. Директор школи повинен бути знаючим, досвідченим педагогом і психологом» [7, с. 395].

Висновки. Психолого-педагогічна спадщина В. О. Сухомлинського досить багатоаспектна, іiї пронизує проблема проєктування людини, яка грунтується на ідеї всебічного розвитку особистості. Ця ідея залишається актуальною і сьогодні. Він мріяв, щоб кожен педагог був не просто «споживачем» педагогічних і психологічних знань, а дослідником і раціоналізатором, творцем. Саме цього вимагає від нас час, саме такі завдання ставлять перед нами учні нової української школи, саме такі можливості відкриває перед нами реформування освіти.

Із метою реалізації завдань нової української школи в контексті новаторського досвіду В. О. Сухомлинського вдосконалення потребує педагогічна і психологічна підготовка вчителів як активних суб'єктів освітніх нововведень через неперервну післядипломну освіту.
Оскільки вона, по-перше, відповідає потребам і закономірностям еволюції інформаційного суспільства та $є$ фактором розвитку й постійного забезпечення психолого-педагогічної культури вчителя, а по-друге, адекватна специфіці освітньої діяльності, ролі та місцю особистості вчителя-інноватора в освітньому процесі, що передбачає безперервне збагачення його професійної компетентності.

\section{СПИСОК ВИКОРИСТАНОЇ ЛІТЕРАТУРИ}

1. Концепція «Нова українська школа» [Електронний ресурс] / Міністерство освіти і науки України. URL: https://mon.gov.ua/storage/app/media/zagalna\%20 serednya/nova-ukrainska-shkola-compressed.pdf (дата звернення: 18.06.2019).

2. Луцюк А. М. Василь Сухомлинський про педагогічну майстерність учителя (до 100-річчя 3 дня народження) : монографія / А. М. Луцюк. - Вид. 2-е, виправ. та доповн. - Луцьк : Вежа-Друк, 2018. - 176 с.

3. Спадщина В. О. Сухомлинського - джерело сучасної педагогічної практики : монографія / авт. кол. : В. О. Сухомлинська, О. Я. Савченко, П. С. Олешко, А. М. Луцюк та ін., упор. П. С. Олешко. - Луцьк : Надстир'я, 2016. - 256 с.

4. Сухомлинський В. О. Наша «скрипка» [Текст] / В. О. Сухомлинський // Рад. освіта. - 1966. -21 травня.

5. Сухомлинський В. О. Методика виховання колективу / В. О. Сухомлинський // Вибр. твори : в 5 т. K., 1976 - 1977. - T. 1. - C. 403-637.

6. Сухомлинський В. О. Павлиська середня школа [Текст] / В. О. Сухомлинський // Вибр. твори : в 5 т. Т. 4. - К. : Рад. шк., 1977. - С. 7-390.

7. Сухомлинський В. О. Розмова з молодим директором / В. О. Сухомлинський // Вибрані твори : в 5-ти т. - Т. 4. - К. : Рідна школа, 1976. - С. 393-626.

8. Сухомлинський В. О. Як виховати справжню людину [Текст] / В. О. Сухомлинський // Вибр. твори : в 5 т. - Т. 2. - К. : Рад. шк., 1976. - С. 149-416.

Дата надходження до редакиії: 09.07.2019 p.

\section{ПРОЦЕС ФОРМУВАННЯ ОСОБИСТОСТІ ДИТИНИ $З$ ОСОБЛИВИМИ ОСВІТНІМИ ПОТРЕБАМИ НА ОСНОВІ ПЕДАГОГІЧНОГО ДИЗАЙНУ В. О. СУХОМЛИНСЬКОГО}

У статті висвітлено питання формування особистості дитини з особливими освітніми потребами на основі педагогічного дизайну В. О. Сухомлинського. Відображено умови родинного виховання та проаналізовано їх важливий вплив на дітей.
Обтрунтовано необхідність професійного розвитку сучасного педагога до побудови інклюзивного простору.

Ключові слова: інклюзивна освіта, діти з особливими освітніми потребами, сімейне виховання, психофізичний розвиток. 